\title{
Increased frequency of circulating IL-21 producing Th-cells in patients with granulomatosis with polyangiitis (GPA)
}

\author{
Wayel H Abdulahad ${ }^{1 *}$, Nikola Lepse ${ }^{2}$, Coen A Stegeman, Minke G Huitema', Berber Doornbos-van der Meer ${ }^{1}$, \\ Henko Tadema ${ }^{1}$, Abraham Rutgers ${ }^{1}$, Pieter C Limburg ${ }^{4}$, Cees GM Kallenberg ${ }^{1}$ and Peter Heeringa ${ }^{2}$
}

\begin{abstract}
Introduction: The present study aimed to explore a possible role for IL-21 producing Th-cells in the immunopathogenesis of granulomatosis with polyangiitis (GPA).

Methods: Peripheral blood from 42 GPA patients in remission and 29 age-matched healthy controls (HCs) were stimulated in vitro, and the frequencies of IL-21 producing Th-cells were determined by flow cytometry. Since Th17-cells produce a low level of IL-21, IL-17 was also included in the analysis. Given that IL-21 is a hallmark cytokine for $T$ follicular helper cells $\left(T_{F H}\right)$, we next evaluated the expression of their key transcription factor BCL-6 by RT-PCR and flow cytometry. To investigate the effect of IL-21 on autoantibody-production, PBMCs from GPA patients were stimulated in vitro with BAFF/LL-21 and total IgG and ANCA levels were measured in supernatants. In addition, the expression of IL-21-receptor on B-cells was analyzed.
\end{abstract}

Results: Percentages of IL-21 producing Th-cells were significantly elevated in GPA-patients compared to HCs, and were restricted to ANCA-positive patients. The expression of BCL-6 was significantly higher in ANCA-positive GPA-patients, as compared with ANCA-negative patients and HCs. IL-21 enhanced the production of IgG and ANCA in vitro in stimulated PBMCs from GPA patients. No difference was found in the expression of the IL-21receptor on B-cells between ANCA-negative patients, ANCA-positive patients, and HCs.

Conclusion: The increased frequency of circulating IL-21 producing Th-cells in ANCA-positive GPA patients and the stimulating capacity of IL-21 on ANCA-production suggest a role for these cells in the immunopathogenesis of GPA. Blockade of IL-21 could constitute a new therapeutic strategy for GPA.

\section{Introduction}

Granulomatosis with polyangiitis (GPA) is an autoimmune vasculitis of small- to medium-sized blood vessels, associated with the presence of circulating anti-neutrophil cytoplasmic autoantibodies (ANCA) that are mainly directed against proteinase 3 [1-3]. Histopathologically, GPA is characterized by granulomatous inflammation and pauciimmune vasculitis, including necrotizing crescentic glomerulonephritis.

Although the production of ANCA is directly attributable to autoreactive B-cells, there is extensive evidence

\footnotetext{
* Correspondence: w.abdulahad@umcg.nl

'Department of Rheumatology and Clinical Immunology, University of Groningen, University Medical Center Groningen, Hanzeplein 1, 9713 GZ, Groningen, The Netherlands

Full list of author information is available at the end of the article
}

that T-cells play a critical role in GPA as well. The immunoglobulin (Ig)G subclass distribution of ANCA, with a preponderance of the IgG1 and IgG4 subclasses, suggests a T-cell-dependent immune response [4]. Infiltrating $\mathrm{T}$-cells in granulomatous lesions and persistent $\mathrm{T}$-cell activation have been observed in GPA patients $[5,6]$. In addition, an aberrant $\mathrm{T}$-cell phenotype and impaired regulatory $\mathrm{T}$-cell function are also reported in GPA patients in remission [7-9], suggesting that even during remission, the immune system is dysregulated. Moreover, T-helper (Th) cell polarization with an increase in Th17 cells has been demonstrated $[10,11]$. Th17 cells and their cytokine IL-17 have been shown to play a critical role in many inflammatory diseases. In addition to IL-17, Th17 cells can produce IL-21, a

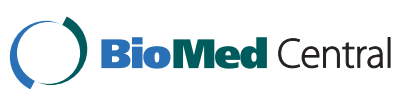


cytokine that is largely responsible for B-cell class switching and antibody production, and which induces differentiation of B-cells towards plasma cells by synergizing with B-cell activating factor (BAFF) $[12,13]$. Therefore, it is conceivable that IL-21 may contribute to the production of pathogenic autoantibodies in GPA.

Multiple studies in animal models indicate a pivotal role of IL-21 in the pathogenesis of autoimmune diseases. Studies in arthritis models have shown that blockade of IL-21 activity reduces joint inflammation and destruction [14]. Subsequent investigations demonstrated that blocking of the IL-21 pathway reduces levels of anti-dsDNA autoantibodies and prevents renal disease in mouse models of systemic lupus erythematosus (SLE) [15]. In addition, mice deficient in IL-21-receptor expression were found to be protected to a large extent against the development of inflammatory bowel disease (IBD) and type-I diabetes $[16,17]$. Interestingly, recent genome-wide association studies have provided convincing evidence that genetic variants in the region on chromosome $4 \mathrm{q} 27$ that harbor the IL-21 and IL-2 genes are associated with chronic inflammatory disorders, including SLE, IBD and psoriasis [18-20]. Thus, IL-21 seems to play an important role in autoimmune diseases in general and could constitute a novel target for therapy.

IL-21 is produced mainly by activated CD $4^{+}$Th-cells. Recent studies have demonstrated that IL-21, besides its production by Th17 cells, is predominantly secreted by a distinct Th-cell lineage, termed follicular helper T-cells $\left(\mathrm{T}_{\mathrm{FH}}\right)$ that express the transcription factor BCL-6 and are considered to be specialized providers of B-cell help [21]. Expansion of circulating $\mathrm{T}$-cells resembling $\mathrm{T}_{\mathrm{FH}}$ cells has been reported in patients with SLE and in patients with rheumatoid arthritis [22-24]. To date, no study has investigated the role of IL-21-producing Th-cells in GPA. Therefore, this study aimed to assess the frequency of IL21-producing Th-cells, and to evaluate whether $\mathrm{T}_{\mathrm{FH}}$ cells or Th17 cells are the major source of IL-21 in GPA patients. For this purpose, we examined the expression of both IL-21 and IL-17 in circulating CD4 $4^{+}$T-cells of patients with GPA. To improve our understanding of the role of IL-21-producing Th cells in autoantibody production we assessed their frequencies in ANCA-positive and ANCA-negative patients, and studied effects of IL-21 on Ig and ANCA production in vitro.

\section{Methods \\ Study population}

Forty-two patients with GPA and 29 age- and sexmatched healthy controls (HC) (18 male, 11 female, mean age $56(\mathrm{SD} \pm 13)$ years, range 26 to 72 years, $P=$ $0.16)$ were included in this study. The diagnosis of GPA was established according to the definitions of the Chapel Hill Consensus Conference and patients fulfilled the classification criteria of the American College of Rheumatology (ACR) $[25,26]$. Only patients without clinical signs and symptoms of active vasculitis and considered to be in complete remission, as indicated by a score of zero on the Birmingham Vasculitis Activity Score (BVAS), were included in the study [27]. Serostatus for ANCA was followed for several months in all patients, and patients with a stable serostatus for ANCA (positive or negative) for at least 3 months were included in this study. Based on these criteria, 23 patients were positive for PR3-ANCA, whereas 19 were ANCA-negative. There was history of generalized disease including renal involvement in 27 patients, and 15 patients had localized disease, which had been confined to the upper and/or lower respiratory tract. None of the patients and controls had infection at the time of sampling. Eleven GPA-patients (eight ANCA-positive, and three ANCA-negative) were treated with maintenance immunosuppressive therapy at the time of blood sampling. Four of them were treated with only azathioprine ( 25 to $100 \mathrm{mg} /$ day), one patient with mycophenolate mofetil (1500 mg/day), and six patients received prednisolone (5 to $10 \mathrm{mg} /$ day) in combination with azathioprine (125 mg/day). Participants in rituximab trials were excluded from the present study. The main clinical and laboratory data from the patients are summarized in Table 1. All patients and healthy individuals provided informed consent and the study was approved by the local Medical Ethics Committee of the University Medical Centre Groningen, University of Groningen (NL).

\section{Measurement of ANCA titres and specificity}

ANCA titers were measured by indirect immunofluorescence (IIF) on ethanol-fixed human granulocytes according to standard procedures as previously described [28]. ANCA titers higher than 1:40 were considered positive.

Table 1 Clinical and laboratory characteristics of patients with granulomatosis with polyangiitis (GPA) at the time of blood sampling

\begin{tabular}{ll}
\hline Characteristic & Value \\
\hline Patients, number & 42 \\
Male/female, number & $26 / 16$ \\
Age, mean \pm SD (range), years & $59 \pm 14(28,81)$ \\
Localized/generalized GPA, number $^{\dagger}$ & $15 / 27$ \\
Positive/negative for PR3-ANCA ${ }^{\dagger}$, number & $23 / 19$ \\
Receiving/not receiving treatment ${ }^{\dagger \dagger}$, number & $11 / 31$ \\
Relapses, median (range), number & $0(0,5)$ \\
Disease duration, median (range), months & $112(20,334)$ \\
\hline
\end{tabular}

${ }^{\dagger}$ Patients were considered to be ANCA-positive when ANCA-titres by IIF were greater than 1:40. ${ }^{\dagger+}$ Four patients were treated with azathioprine only, one with mycophenolate mofetil, and six patients received prednisolone in combination with azathioprine. GPA, granulomatosis with polyangiitis; PR3, proteinase 3; ANCA, antineutrophil cytoplasmic antibody. 
ANCA antigenic specificity was determined using an inhouse capture ELISA as described before [29,30]. Briefly, a 96-well plate was coated with goat-anti-mouse Ig for 48 hours. After washing, plates were incubated with mouse monoclonal antibody against human PR3 for 2 hours. After washing, the plate was incubated overnight at $4^{\circ} \mathrm{C}$ with an extract of human azurophilic granules, which were isolated from neutrophils of healthy donors. Further, serial dilutions of serum (with a starting dilution of $1: 100$ ) were incubated for 1 hour. The plate was washed, and the captured antibodies were detected with purified $\mathrm{F}(\mathrm{ab})_{2}$ goat-anti-human IgG conjugated to alkaline phosphatase. P-nitrophenylphosphate disodium was used as a substrate, and the optical density was measured at $405 \mathrm{~nm}$.

\section{Antibodies used in flow cytometry}

The following conjugated antibodies were used in flow cytometry: allophycocyanin (APC)-conjugated anti-CD3 (clone UCHT1), peridin chlorophyll protein (PerCP)conjugated anti-CD8 (clone SK1), phycoerythrin (PE)conjugated anti-IL-21-receptor (clone 17A12), and PerCP-conjugated anti-CD19 (clone 4G7), all purchased from Becton \& Dickinson (Amsterdam, The Netherlands); PE-conjugated anti-IL-21 (clone eBio3A3-N2), Alexa Fluor $^{\circledR} 488$ (A488)-conjugated anti-IL-17 (clone eBio64DEC17), and A488-conjugated anti-FoxP3 (clone PCH101), all purchased from eBioscience (San Diego, CA, USA); and PE-conjugated anti-BCL-6 (clone IC5046P) obtained from R\&D Systems (Minneapolis, MN, USA).

\section{Sample preparation and in vitro stimulation}

Lithium-heparinized venous blood was obtained from patients and healthy donors. Immediately after sampling, $400 \mu \mathrm{L}$ blood was mixed with $400 \mu \mathrm{L}$ RPMI1640 (Cambrex Bio Science, Verviers, Belgium), supplemented with $50 \mu \mathrm{g} / \mathrm{ml}$ gentamycin (Gibco, Scotland, UK), and aliquoted in two 5 - $\mathrm{mL}$ polypropylene tubes (BD Biosciences, Amsterdam, The Netherlands) (400 $\mu \mathrm{L}$ per tube). Diluted blood samples were stimulated 4 hours with 50 ng/mL phorbol myristate acetate (PMA; Sigma-Aldrich, Steinheim, Germany) and $2 \mathrm{nM}$ calcium ionophore (Ca-Io; Sigma-Aldrich). As a negative control, one sample was kept in medium only without stimulation. For inhibiting cytokine release from the cells, $10 \mu \mathrm{g} / \mathrm{ml}$ of brefeldin A (Sigma-Aldrich) was added to each sample.

\section{Intracellular fluorescence-activated cell sorter (FACS)- staining for cytokines}

After stimulation cells were washed in wash buffer (PBS, $5 \%$ fetal bovine serum (FBS), $0.1 \%$ sodium azide (Merk, Germany)] and stained with PerCP-conjugated anti-CD8 and APC-conjugated anti-CD3 for 15 minutes at room temperature. Cells were fixed with $100 \mu \mathrm{L}$ Reagent A (Caltag/Invitrogen., Breda, The Netherlands) for 10 minutes. After washing, the pellet was resuspended in $100 \mu \mathrm{L}$ permeabilization Reagent B (Caltag/Invitrogen) and labeled with A488-conjugated anti-IL-17 and PE-conjugated antiIL-21 for 20 minutes in the dark. After staining, the cells were washed and immediately analyzed on the FACSCalibur flow cytometer (Becton \& Dickinson). Data were collected for $2 \times 10^{5}$ cells, and plotted using the Win-List software package (Verity Software House Inc, ME, USA) ME, USA). Because stimulation reduces surface expression of CD4 on T-cells, CD4 ${ }^{+} \mathrm{T}$-cells were identified indirectly by gating on CD3-positive and CD8-negative lymphocytes. Gated $\mathrm{CD}_{4}^{+} \mathrm{T}$-cells were further displayed as a dot plot for evaluation of intracellular cytokine production. The unstimulated control sample was used as a guide for setting the linear gates to discriminate positive and negative populations.

\section{Intracellular staining for transcription factors}

Peripheral blood mononuclear cells (PBMCs) from GPA patients and HCs were prepared from heparinized venous blood by density-gradient centrifugation on Lymphoprep (Axis-Shield PoC AS, Oslo, Norway). Cells recovered from the gradient interface were washed twice in PBS and stained for BCL- 6 and FoxP3 according to the manufacturer's instructions (eBioscience staining set for transcription factors). Briefly, PBMCs were adjusted to $1 \times 10^{6}$ cells in $100 \mu \mathrm{L}$ and incubated with appropriate concentration of APC-conjugated anti-CD3 and PerCP-conjugated anti$\mathrm{CD} 8$ for 30 minutes at $4{ }^{\circ} \mathrm{C}$ in the dark, followed by fixation and permeabilizaion in Fix/Perm buffer (eBioscience) for 45 minutes. Cells were then washed twice with $1 \times$ permeabilization buffer (eBioscience), and stained with PE-conjugated anti-BCL-6 and A488-conjugated antiFoxP3. After incubation for 30 minutes in the dark, the cell suspension was washed and immediately analyzed on the FACS-Calibur flow cytometer (Becton \& Dickinson). Lymphocytes were gated by forward and side scatter patterns, and plotted using the Win-List software package (Verity Software House Inc). Isotype matched control antibodies of irrelevant specificity were obtained from eBioscience and R\&D systems.

\section{Immunofluorescent surface staining for IL-21R on B-cells} Fresh blood samples from GPA patients and HCs were labeled with PE-conjugated anti-IL21R, and PerCP-conjugated anti-CD19 for 15 minutes in the dark. Cells were successively treated with $2 \mathrm{~mL}$ diluted FACS lysing solution (BD, Amsterdam, The Netherlands) for 10 minutes and then washed twice in wash buffer and immediately analyzed by flow cytometry. 
RNA isolation and real-time reverse transcription (RT)-PCR Erythrocytes were lysed and leukocytes were fixed and washed twice in 1\% BSA. RNA was isolated from total leukocytes with TRIzol reagent (Invitrogen) according to the manufacturer's instructions. DNAse treatment (Ambion, Huntingdon, Cambridgeshire, UK) was performed and subsequently cDNA was synthesized using M-MLV reverse transcriptase and oligo (dT) 14 to 18 as primer. For measurement of mRNA for BCL-6 and glyceraldehyde-3-phosphate dehydrogenase (GAPDH), $1 \mu \mathrm{L}$ of cDNA in triplicate was used for amplification by the Taqman RT-PCR system (ABI Prism 7900HT Sequence Detection System, Applied Biosystems, Foster City, CA, USA) with specific Taqman primers/probes (BCL-6 (Hs 00153368_m1) and GAPDH (Hs 99999905_m1), Applied Biosystems). Amplification was performed using standard conditions and calculations of fold induction were performed. We normalized gene expression to GAPDH and expressed values relative to control using the ${ }^{\Delta \Delta} \mathrm{CT}$ (cycle threshold) method.

\section{Cell stimulation and total lgG production}

PBMCs recovered from the gradient interface were washed twice in PBS and adjusted to $10^{6}$ cells $/ \mathrm{mL}$ in RPMI 1640 (Lonza, Basel, Switzerland) supplemented with $10 \%$ FCS (Lonza, Switzerland) and $50 \mu \mathrm{g} / \mathrm{mL}$ gentamicin (GIBCO, Invitrogen). Cells were cultured in the presence of $100 \mathrm{ng} / \mathrm{mL}$ rhIL-21 (ImmunoTools $\mathrm{GmbH}$, Friesoythe, Germany) and/or $100 \mathrm{ng} / \mathrm{mL} \mathrm{rhBAFF}$ (PeproTech, NJ, USA) for 12 days at $37^{\circ} \mathrm{C}$ with $5 \% \mathrm{CO}_{2}$. After 12 days, culture supernatants were collected and total IgG was measured using an in-house ELISA as described previously [31]. Briefly, Costar 96-well ELISA plates were coated with $2 \mathrm{mg} / \mathrm{mL}$ goat anti-human-Ig antibody (Southern Biotech, Birmingham, AL, USA) in carbonate buffer (0.01 M, pH 9.6). Plates were washed with washing buffer $(0.025 \mathrm{M}$ Tris- $\mathrm{HCl}, 0.15 \mathrm{M} \mathrm{NaCl}$, $0.05 \%$ Tween-20) and blocked for 1 hour with blocking/ incubation-buffer $(0.05 \mathrm{M}$ Tris- $\mathrm{HCl}, 0.3 \mathrm{M} \mathrm{NaCl}, 0.05 \%$ Tween-20, 1\% BSA). Cell culture supernatants were diluted in incubation buffer. Purified human IgG with a known concentration was used as a standard sample. The bound IgG was detected with goat-anti-human-IgG antibody conjugated with alkaline phosphatase (Sigma, St Louis, MO, USA). P-nitrophenyl-phosphate disodium was used as substrate and optical density was read at $405 \mathrm{~nm}$ using an Emax microplate reader (Molecular Devices, Silicon Valley, CA, USA).

\section{Measurement of in vitro production of PR3-ANCA}

In vitro PR3-ANCA IgG production in PBMC culture supernatants was measured by Phadia ImmunoCAP ${ }^{\circledR}$ 250 analyzer (Thermo Fisher Scientific, MA, USA) using
ELiA $^{\mathrm{TM}} \mathrm{PR} 3$, and the levels of PR3-ANCA IgG production were expressed in response units (RU).

\section{Statistical analysis}

Data are presented as median values unless stated otherwise. The nonparametric Mann-Whitney $U$-test was used to compare data from patients with those of HCs. The Wilcoxon matched pairs test was used for intraindividual comparison. Correlations were assessed using Spearman's rank correlation coefficient. Two-tailed $P$-values lower than 0.05 were considered statistically significant.

\section{Results}

Increased percentage of circulating IL- $21^{+} \mathrm{IL}-17^{-}$cells in ANCA-positive GPA patients compared to ANCA-negative patients and healthy controls

We initially determined the frequency of IL-21-producing CD4 T-cells in the peripheral blood of GPA patients $(n=$ $42)$ and HCs $(n=29)$ after in vitro stimulation. The percentage of circulating IL- $21^{+}$Th-cells was significantly higher in GPA patients compared with the control group (Figure 1B). Of note, Th17 cells may produce IL-21 in addition to their signature cytokine IL-17. Since Th17 cells are increased in GPA patients $[10,11]$, we next extended our analysis to investigate whether increased IL- $21^{+}$Th-cells in GPA patients resulted from an increase in Th17 cells. To this end, IL-17 staining was included in the analysis to determine what percentage of the total IL- $21^{+}$Th-cells are Th17 cells. Using this approach, we assessed the frequency of IL- $21^{+} \mathrm{IL}-17^{-}, \mathrm{IL}-21^{+} \mathrm{IL}-17^{+}$, and IL-21 ${ }^{-} \mathrm{IL}-17^{+}$cells within the CD4 T-cells in GPA patients and HCs. As shown in Figure (1C, D and 1E), GPA patients in remission had a significantly higher percentages of circulating IL- $21^{+} \mathrm{IL}-17^{-}$, IL- $21^{+} \mathrm{IL}-17^{+}$, and IL-21 $\mathrm{IL}-17^{+}$ cells compared with the control group. However, the majority of circulating $\mathrm{CD} 4^{+} \mathrm{T}$-cells that produced only IL-21 were distinct from Th17 cells, that is, negative for IL-17. To assess the possible role of IL- $21^{+} \mathrm{IL}-17^{-}$Th-cells in ANCA production, we compared their percentage between patients who were ANCA-positive $(n=23$; IIF titer $>1: 40)$ or ANCA-negative $(n=19)$ at the time of inclusion. Significant increases in the frequencies of IL-21 ${ }^{+}$IL-17- Th-cells were observed in ANCA-positive patients in comparison with $\mathrm{HCs}$ and ANCA-negative patients, whereas no significant difference was found between ANCA-negative patients and HCs (Figure 1F). In contrast, the percentages of IL- $21^{+} \mathrm{IL}-17^{+}$and IL- $21^{-} \mathrm{IL}-17^{+}$Th-cells in ANCA-positive GPA patients did not differ from those in ANCA-negative GPA-patients (Figure $1 \mathrm{G}$ and $1 \mathrm{H}$ ). These results suggest that persistence of IL- $21^{+} \mathrm{IL}-17^{-}$Thcells during remission plays a role in the ongoing humoral autoimmune response in ANCA-positive GPA patients. 


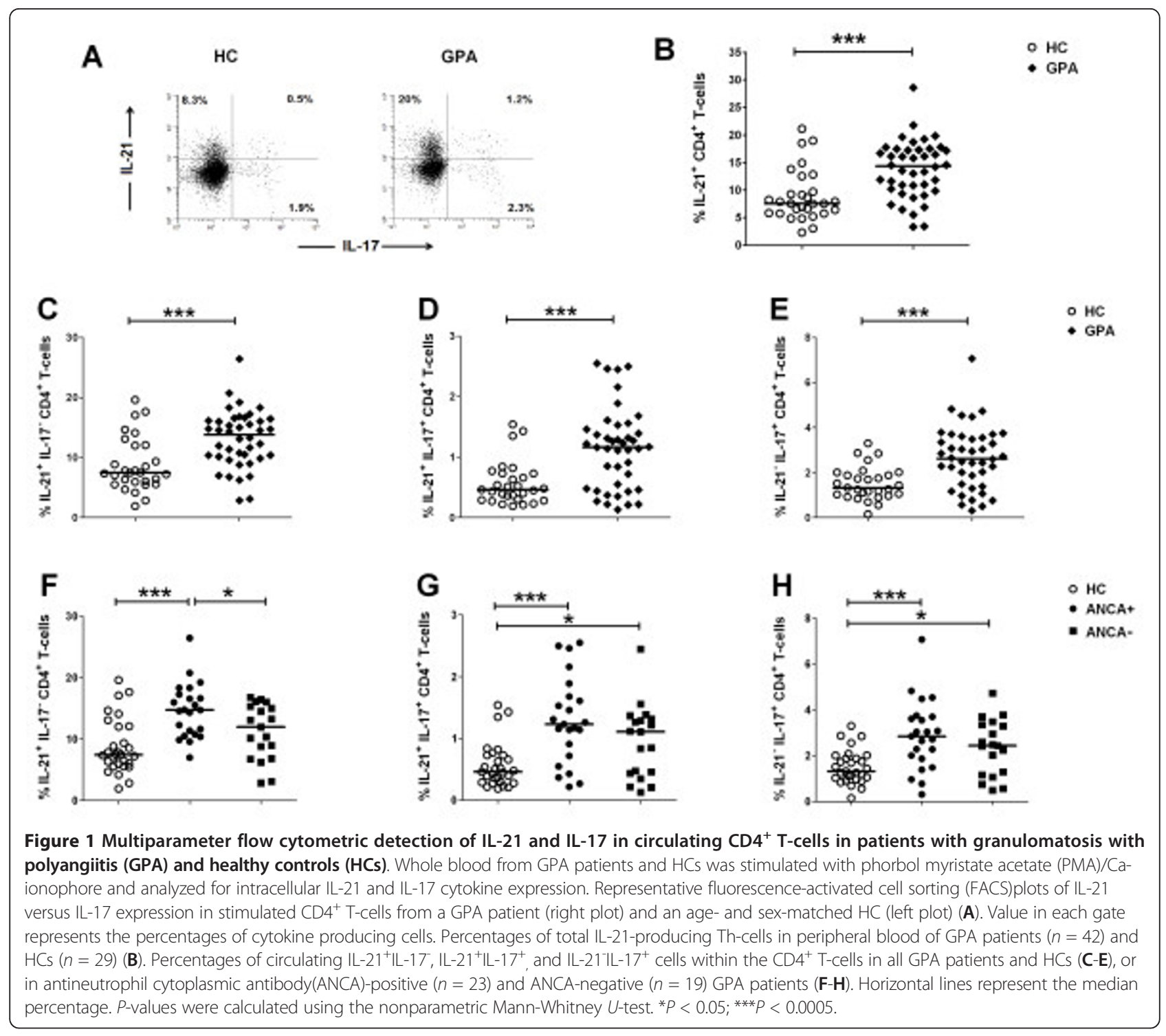

To rule out the possibility that the increased proportion of IL-21 ${ }^{+} \mathrm{IL}-17^{-}$Th-cells in GPA patients was the result of current treatment, the ANCA-positive patient group was divided into treated and untreated patients, and the percentages of IL- $21^{+} \mathrm{IL}-17^{-}$Th-cells were compared. No significant differences were observed between treated and untreated patients (data not shown). We also compared the percentage of IL-21 ${ }^{+} \mathrm{IL}-17^{-} \mathrm{Th}$-cells between currently untreated ANCA-positive patients with a history of generalized disease and those with localized disease. No difference was found between these patient groups (data not shown).

\section{Increased frequencies of IL- $21^{+}$IL-17- Th-cells correlate} positively with $\mathrm{Th} 17$ response

It has been reported that IL-21 is a key factor regulating the differentiation of naïve $\mathrm{CD}^{+}{ }^{+} \mathrm{T}$-cells into Th17 cells
$[32,33]$. In order to analyze this relationship, we tested correlation between percentages of IL- $21^{+} \mathrm{IL}-17^{-}$Th-cells and percentages of terminally differentiated Th17 cells $\left(\mathrm{IL}-21^{-} \mathrm{IL}-17^{+}\right)$in GPA patients $(n=42)$ and HCs $(n=$ 29). Interestingly, a significant positive correlation was observed between IL-21 ${ }^{+} \mathrm{IL}-17^{-}$Th-cells and IL-21 IL-17 Th-cells in both GPA patients and HCs $(r=0.58, P<$ 0.0001 and $r=0.37, P=0.04$, respectively) (Figure $2 \mathrm{~A}$ and $2 \mathrm{~B})$.

\section{Increased frequencies of $\mathrm{BCL}-6^{+} \mathrm{CD} 4^{+} \mathrm{T}$-cells in peripheral blood of ANCA-positive GPA patients}

Since IL-21 is not the only marker for $\mathrm{T}_{\mathrm{FH}}$ cells, we further characterized the identity of circulating IL-21producing cells by analyzing BCL-6 expression, which is considered a master regulator and specific transcription 


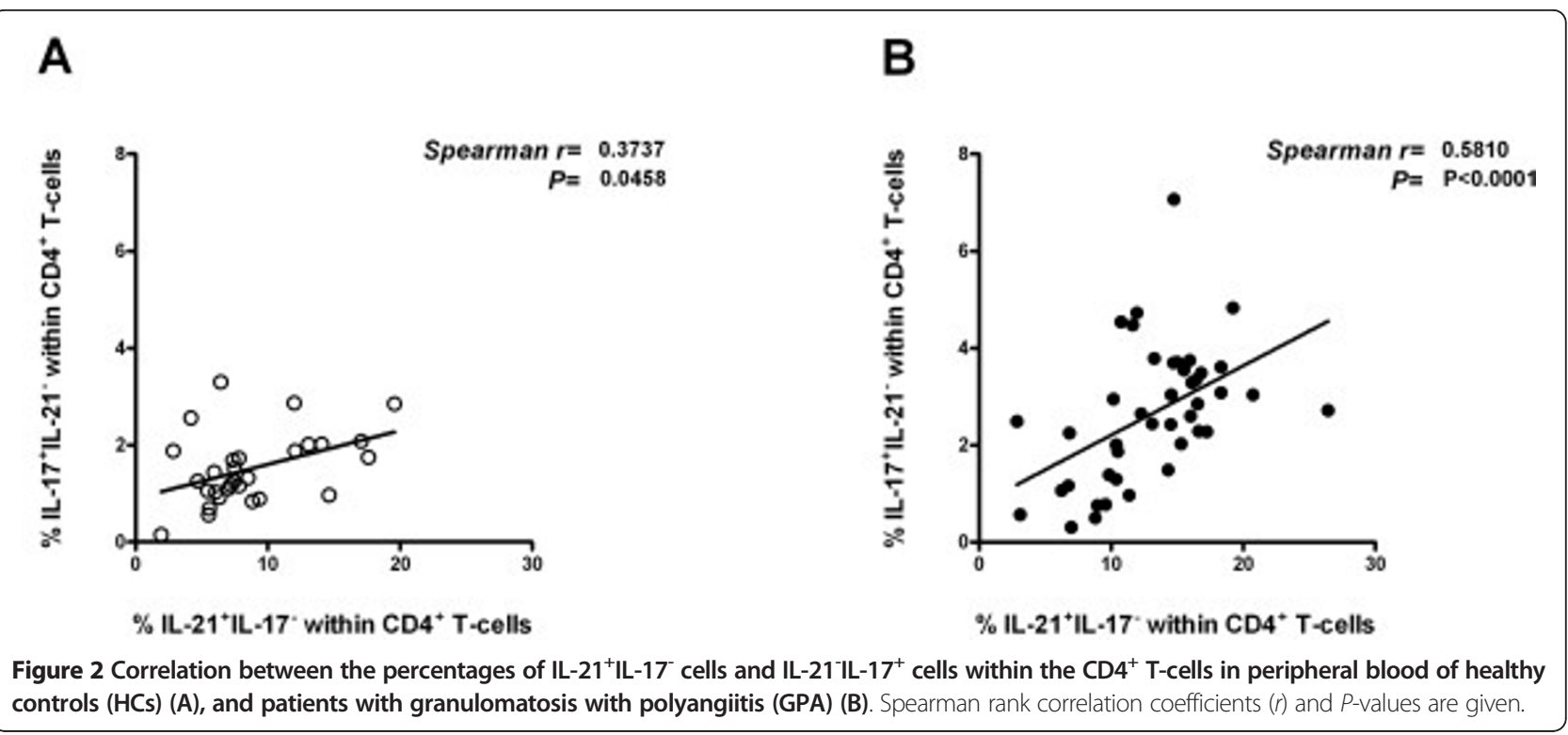

factor for $\mathrm{T}_{\mathrm{FH}}$ cells $[34,35]$. To this end, the expression of mRNA BCL- 6 was assessed in circulating leukocytes from GPA patients and HCs by real-time RT-PCR. Restricted numbers of patients and controls were included in this analysis due to insufficient cell numbers. Patients with ANCA-positive GPA $(n=10)$ had a significantly higher expression of mRNA BCL-6 than ANCAnegative patients $(n=6)$ and $\operatorname{HCs}(n=11)$ (Figure 3B). In addition, intracellular FACS-staining for BCL- 6 within circulating CD4+ T cells confirmed the increased BCL-6 expression in ANCA-positive GPA patients (Figure 3A and $3 \mathrm{C}$ ). We have also analyzed the MFI (mean fluorescence intensity) of BCL- 6 expression in $\mathrm{CD}^{+}{ }^{+} \mathrm{T}$-cells from patients and $\mathrm{HCs}$ and found that the expression level of BCL-6 per Th-cell in GPA patients was similar to that in HCs (data not shown). Thus, BCL-6 expression is increased in GPA patients due to increased frequencies of circulating BCL- $6^{+} \mathrm{CD} 4^{+} \mathrm{T}$-cells.

Because in recent studies a new population of FoxP3 ${ }^{+}$ regulatory $\mathrm{T}$-cells has been described that shares features with $\mathrm{T}_{\mathrm{FH}}$ cells by expressing the transcription factor BCL6 , we also evaluated whether the increase in BCL- $6^{+}$ $\mathrm{T}$-cells in GPA patients was a result of an increase in FoxP ${ }^{+}{ }^{B C L}-6^{+}$T-cells $[36,37]$. This analysis showed that the increase in BCL- 6 expression in GPA patients was restricted to $\mathrm{T}_{\mathrm{FH}}$ cells and although a low percentage of FoxP3 ${ }^{+} \mathrm{BCL}-6^{+} \mathrm{T}$-cells was found $(<0.3 \%)$, no differences in these cell frequencies were observed between GPA patients and HCs (data not shown).

Proportions of IL-21-receptor expressing B-cells do not differ between GPA patients and healthy controls

Since it is well known that IL-21 acts on B-cells to support their expansion and antibody production [38-40], we conducted further analysis to compare the expression of IL-21R on B cells from GPA patients and HCs. No differences were seen in the percentages of IL-21R ${ }^{+}$ B-cells either between ANCA-positive $(n=13)$ and ANCA-negative patients $(n=14)$ or between patients and HCs $(n=19)$ (Figure 4$)$.

\section{IL-21 induces IgG and ANCA production by B-cells from GPA patients}

To explore the interplay between IL-21-producing Thcells and B-cells in GPA patients, we investigated the effect of IL-21 on IgG antibody-production by B-cells from GPA patients. Restricted numbers of patients and controls were enrolled in this analysis due to insufficient cell numbers. PBMCs from GPA patients were cultured in vitro in the presence or absence of exogenous IL-21 for 12 days and total IgG was measured in supernatants by ELISA. Because IL-21 promotes B-cell differentiation by synergizing with BAFF $[12,13]$, we questioned whether the effect of IL-21 on IgG production could be augmented by adding BAFF to the culture. Of note, autologous $\mathrm{T}$-cells in our culture system act as a natural provider of CD40 ligation for B-cells, as this ligation is required for $\mathrm{B}$-cell activation, isotype switching and memory development. As shown in Figure 5, IL-21 significantly enhanced the production of IgG in vitro in stimulated PBMCs from both ANCA-positive $(n=7)$ and ANCA-negative $(n=6)$ GPA-patients, whereas stimulation with BAFF alone did not result in increased IgG production. The combination of BAFF and IL-21 tended to increase IgG production more than IL-21 alone. Next, we assessed the effect of IL-21 plus BAFF on in vitro production of PR3-ANCA. As shown in Figure 5B, spontaneous PR3-ANCA production was observed in 


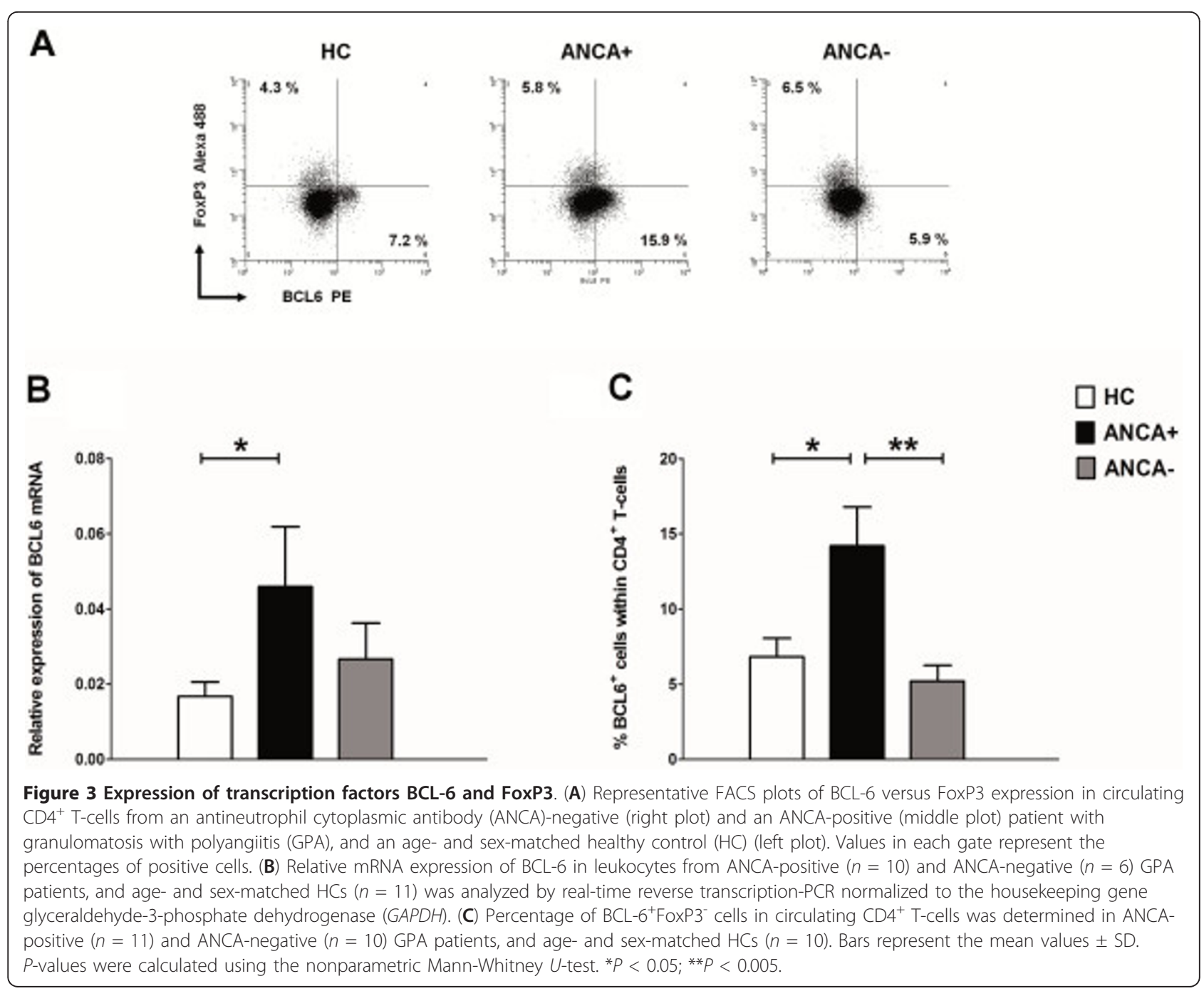

cultured PBMCs from ANCA-positive patients $(n=16)$ in comparison with cells from ANCA-negative patients $(n=12)$. Importantly, IL-21 induces a significant enhancement in PR3-ANCA production in PBMCs isolated from ANCA-positive patients in comparison with ANCA-negative patients. So it is conceivable that autoreactive $\mathrm{B}$-cells were enriched in the peripheral blood of ANCA-positive patients.

\section{Discussion}

In the present study, we demonstrate an increase in the percentage of circulating IL-21-producing Th-cells in GPA patients. We found that elevated frequencies of IL21-producing Th-cells were restricted to ANCA-positive GPA patients and that these cells were distinct from Th17-cells. We also confirmed that IL-21 can enhance the production of IgG and ANCA in vitro.

Over the past few years, Th17-cells have challenged the classical Th1/Th2 paradigm, and have been implicated in a growing number of autoimmune and inflammatory diseases [41]. Recently, a distinct Th-cell subset termed $\mathrm{T}_{\mathrm{FH}}$ and characterized by elevated expression levels of multiple surface proteins and BCL- 6 as well as enhanced IL-21 secretion, have been identified as true helper cells for antibody responses. We and others have previously demonstrated that circulating Th17-cells are significantly increased in GPA patients even during quiescent disease $[10,11]$. However, data are lacking to support a role of IL-21-producing Th-cells in GPA. Since Th17 cells also produce IL-21, we investigated whether Th17 cells in GPA are a source of IL-21. Strikingly, the majority of circulating CD4 T-cells that produced IL-21 were distinct from Th17 cells, indicating that other Th-cell subsets such as $\mathrm{T}_{\mathrm{FH}}$ cells are the source of this cytokine. Importantly, the expansion of $\mathrm{T}_{\mathrm{FH}}$ cells in GPA patients was confirmed by increased BCL- 6 expression. To the best of our knowledge, this is the first report demonstrating an increase in the frequency of circulating IL-21-producing 


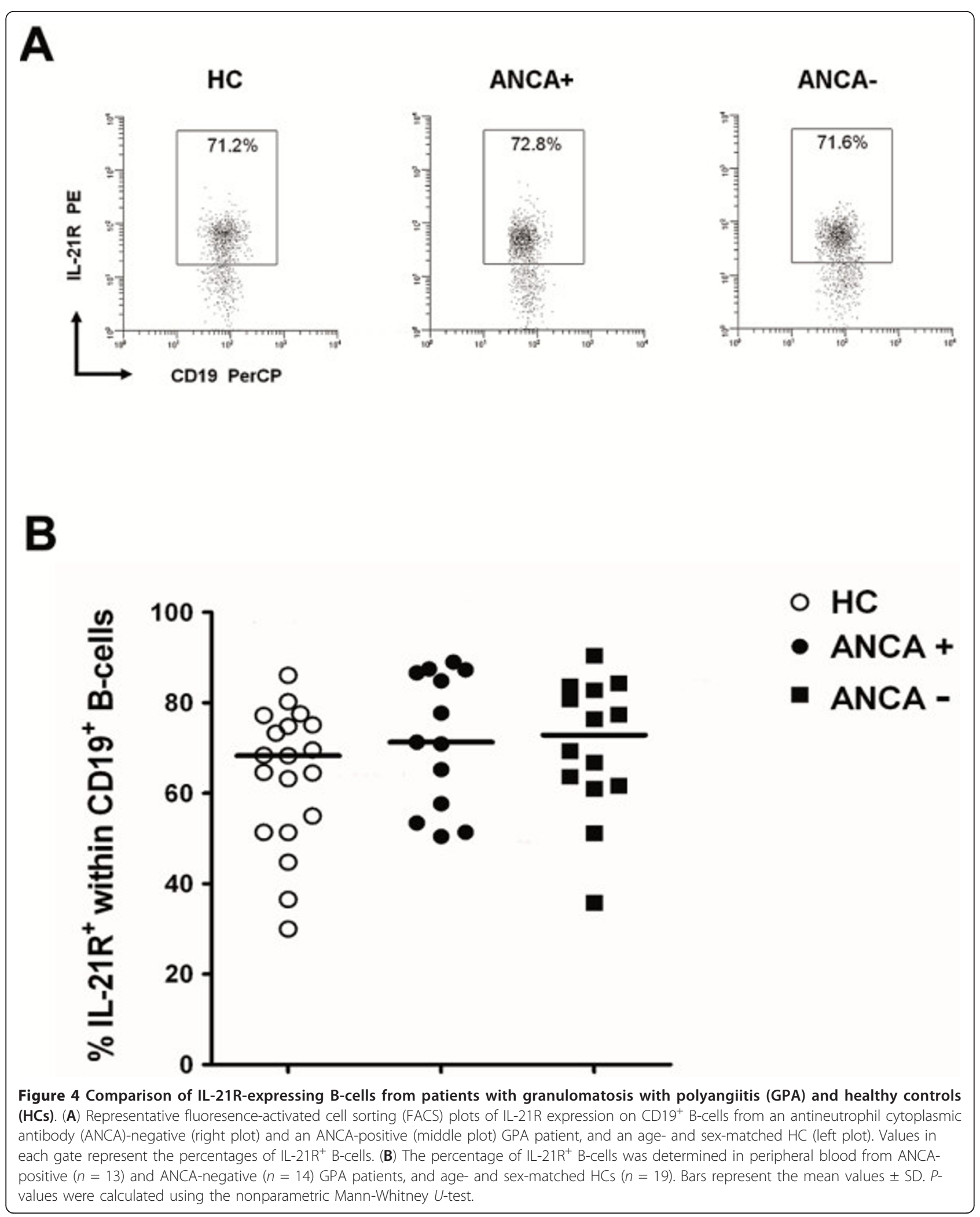




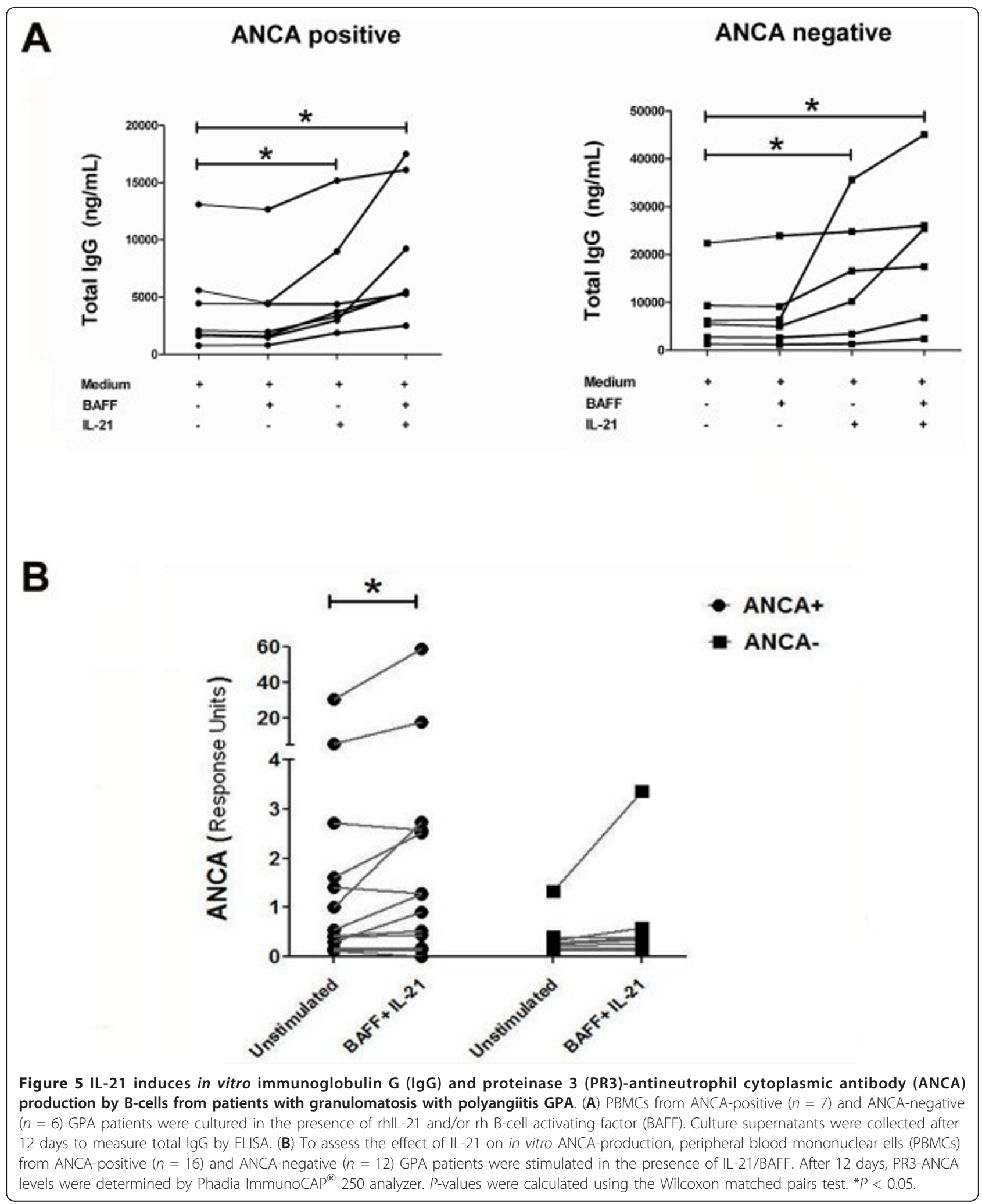

Th-cells in GPA, suggesting that $\mathrm{T}_{\mathrm{FH}}$ cell-derived IL-21 may contribute to disease pathogenesis via stimulation of (auto)antibody production.
$\mathrm{T}_{\mathrm{FH}}$ cells are considered to be the major source of IL-21 and seem to be an important subset for adaptive immune responses, although there are conflicting 
reports on their mode of action in vivo. It has been demonstrated that IL-21-producing Th-cells induce Th17 development and proliferation [32,33], which has been shown to promote germinal center (GC) formation in a BXD2 mouse model of autoimmunity [42]. In agreement with these findings, we demonstrate a significant positive relationship between IL-17 ${ }^{+} \mathrm{IL}-21^{-}$Th-cells and IL-17- IL-21 ${ }^{+}$Th-cells in peripheral blood of GPA patients. It seems likely that increased Th17 cells in GPA-patients are the result of an enhanced $\mathrm{T}_{\mathrm{FH}}$ response, which in turn may participate in granuloma formation and vascular damage. The role of IL-21 in vasculitis was previously suggested by Chen and coworkers [43]. In their study, mice deficient in interferon regulatory factor-4, a protein that inhibits IL-17A production, rapidly developed large-vessel vasculitis and showed increased IL-21 synthesis in addition to increased IL-17A production [43]. Moreover, a role of IL-21 in recruitment of Th17-cells to inflamed tissues has been reported by Caruso and coworkers [44] by showing that IL-21 induces gut epithelial cells to secrete macrophage inflammatory protein-3 $\alpha$ (MIP-3 $\alpha$ ), a chemokine that mediates Th17-cell homing to the skin, joints, and mucosal tissues. Given that endothelial cells are known to produce MIP$3 \alpha$, it is possible that IL-21 in GPA patients enhances the migration and accumulation of Th17-cells into the vascular wall resulting in inflammation. Besides, IL-21 was shown to enhance granzyme B expression [45] and increase perforin-mediated cytotoxicity by human CD8 T-cells [46] and natural killer cells [47]. It is therefore conceivable that IL-21 can contribute to vessel injury and disease progression in GPA patients. This is an area worth of further investigation.

In contrast to the pro-inflammatory role of $\mathrm{T}_{\mathrm{FH}}$ cells, recent studies have identified a distinctive population of $\mathrm{T}_{\mathrm{FH}}$ cells that displays a regulatory function and suppresses the differentiation of GC B-cells in follicles in vivo. This subset was termed follicular regulatory $\mathrm{T}$-cells $\left(\mathrm{T}_{\mathrm{FR}}\right)$, which express the regulatory transcription factor FoxP3 in addition to their specific lineage transcription factor BCL$6[36,37]$. As circulating FoxP3 ${ }^{+} \mathrm{T}$-cells are increased in GPA patients [7], it is conceivable that the observed increase in $\mathrm{T}_{\mathrm{FH}}$ cells in patients is due to an increase in $\mathrm{T}_{\mathrm{FR}}$ cells that co-express FoxP3 and BCL-6. We have investigated this possibility but found that the increase in circulating $\mathrm{T}_{\mathrm{FH}}$ cells in GPA patients cannot be explained by increase in $\mathrm{T}_{\mathrm{FR}}$ cells (data not shown).

In our study, increased frequencies of $\mathrm{T}_{\mathrm{FH}}$ cells were observed in patients who were ANCA-positive at the time of inclusion. This suggests the involvement of IL21 in the process of autoantibody production in GPA. These data are in line with previous reports showing that $\mathrm{T}_{\mathrm{FH}}$ cells act directly on B-cells through the IL-21/ IL-21R pathway, and that IL-21 is a potent inducer of class-switch recombination and plasma cell differentiation $[39,48,49]$. The expression of IL-21R on B-cells from ANCA-positive and ANCA-negative GPA patients was comparable, which suggests that both patient populations have the same ability to respond to IL- 21 . However, in vitro stimulation with IL-21 enhanced the production of ANCA in cell cultures from ANCApositive patients only, although enhanced total IgG-production was observed in both patient groups. So it is conceivable that autoreactive $\mathrm{B}$-cells were enriched in the peripheral blood of ANCA-positive patients. This might be clinically relevant as well, because ANCApositive patients are at increased risk for disease relapse $[50,51]$.

In this study, patients were evaluated for the distribution of $\mathrm{T}_{\mathrm{FH}}$ cells during remission. We have previously shown that activated $\mathrm{T}$-cells are present at the time of clinically quiescent disease $[9,10]$. Furthermore, during active disease effector T-cells appear to migrate towards inflamed tissue [52]. Therefore, in order to study dysbalance of T-cells in GPA patients using peripheral blood samples, we choose to- select patients without or with low dosages of immunosuppressive medication and at the time of clinically quiescent disease.

\section{Conclusions}

In conclusion, the data presented here demonstrate a prominent increase of circulating $\mathrm{T}_{\mathrm{FH}}$ cells in ANCApositive GPA patients. The key cytokine of these $\mathrm{T}_{\mathrm{FH}}$ cells, that is IL-21, contributes to the production of ANCA autoantibodies in vitro. These data support the notion that $\mathrm{T}_{\mathrm{FH}}$ cells are associated with the pathogenic process in GPA patients and may constitute a novel target for therapeutic intervention.

\section{Abbreviations}

ANCA: anti-neutrophil cytoplasmic autoantibodies; A488: Alexa Fluor ${ }^{{ }_{\circledast}}$ 488; APC: allophycocyanin; BAFF: B-cell activating factor; BVAS: Birmingham Vasculitis Activity Score; Ca-l: calcium ionophore; ELISA: enzyme-linked immunosorbent assay; FACS: fluorescence-activated cell sorter; FBS: fetal bovine serum; FCS: fetal calf serum; FITC: fluorescein isothiocyanate; $T_{F H}$ : follicular helper T-cells; GAPDH: glyceraldehyde-3-phosphate dehydrogenase; GC: germinal center; GPA: granulomatosis with polyangiitis; HC: healthy control; IBD: inflammatory bowel disease; Ig: immunoglobulin; IIF: indirect immunofluorescence; IL-21: interleukin-21; IL-21R: interleukin-21 receptor; MIP-3a: macrophage inflammatory protein-3a; MFI: mean fluorescence intensity; PB: peripheral blood; PBMC: peripheral blood mononuclear cells; PBS: phosphate-buffered saline; PE: Phycoerythrin; PerCP: peridin chlorophyll protein; PMA: phorbol myristate acetate; PR3: proteinase 3; RT-PCR: reverse transcription-polynerase chain reaction; RU: response units; SLE: systemic lupus erythematosus; Th: T-helper; TFR: follicular regulatory T-cells.

\section{Competing interests}

The authors declare that they have no competing interests.

\section{Authors' contributions}

All authors contributed to the design, acquisition of data, analysis and interpretation of data. WHA contributed to concept and design, performed the statistical analysis, and had full access to all of the data in the study and 
takes responsibility for the integrity of the data and the accuracy of the data analysis. WHA, NL, MGH, BDvdM, and HT performed the flow cytometry, in vitro experiments, RT-PCR experiments, interpretation of data, and drafting of the manuscript. CAS and AR contributed to concept and design, inclusion of GPA patients, analyses and interpretation of clinical data, and drafting of the manuscript. PCL, PH, and CGMK contributed to concept and design, interpretation of data and revising the manuscript for important intellectual content. All authors read and approved the final manuscript.

\section{Acknowledgements}

We are grateful to the patients and healthy donors for their co-operation and participation in this study. The research leading to these results has received funding from the European Union Seventh Framework Programme (FP7/2007-2013) under grant agreement $n^{\circ}$ 261382, and from the Groningen University Institute for Drug Exploration (GUIDE).

\section{Authors' details}

'Department of Rheumatology and Clinical Immunology, University of Groningen, University Medical Center Groningen, Hanzeplein 1, 9713 GZ, Groningen, The Netherlands. ${ }^{2}$ Department of Pathology and Medical Biology, University of Groningen, University Medical Center Groningen, Hanzeplein 1, 9713 GZ, Groningen, The Netherlands. ${ }^{3}$ Department of Nephrology, University of Groningen, University Medical Center Groningen, Hanzeplein 1, 9713 GZ, Groningen, The Netherlands. ${ }^{4}$ Department of Laboratory Medicine, University of Groningen, University Medical Center Groningen, Hanzeplein 1, 9713 GZ, Groningen, The Netherlands.

Received: 16 January 2013 Revised: 26 April 2013

Accepted: 24 June 2013 Published: 24 June 2013

\section{References}

1. Fauci AS, Haynes BF, Katz P, Wolff SM: Wegener's granulomatosis: prospective clinical and therapeutic experience with 85 patients for 21 years. Ann Intern Med 1983, 98:76-85.

2. van der Woude FJ, Rasmussen N, Lobatto S, Wiik A, Permin H, van Es LA, van der GM, van der Hem GK, The TH: Autoantibodies against neutrophils and monocytes: tool for diagnosis and marker of disease activity in Wegener's granulomatosis. Lancet 1985, 1:425-429.

3. Niles JL, McCluskey RT, Ahmad MF, Arnaout MA: Wegener's granulomatosis autoantigen is a novel neutrophil serine proteinase. Blood 1989, 74:1888-1893.

4. Brouwer E, Tervaert JW, Horst G, Huitema MG, van der GM, Limburg PC, Kallenberg CG: Predominance of lgG1 and lgG4 subclasses of antineutrophil cytoplasmic autoantibodies (ANCA) in patients with Wegener's granulomatosis and clinically related disorders. Clin Exp Immunol 1991, 83:379-386.

5. Komocsi A, Lamprecht P, Csernok E, Mueller A, Holl-Ulrich K, Seitzer U, Moosig F, Schnabel A, Gross WL: Peripheral blood and granuloma CD4(+) CD28(-) T cells are a major source of interferon-gamma and tumor necrosis factor-alpha in Wegener's granulomatosis. Am J Pathol 2002, 160:1717-1724.

6. Lamprecht P, Moosig F, Csernok E, Seitzer U, Schnabel A, Mueller A, Gross WL: CD28 negative T cells are enriched in granulomatous lesions of the respiratory tract in Wegener's granulomatosis. Thorax 2001, 56:751-757.

7. Abdulahad WH, Stegeman CA, van der Geld YM, Doornbos-van der MB, Limburg PC, Kallenberg CG: Functional defect of circulating regulatory $\mathrm{CD} 4+\mathrm{T}$ cells in patients with Wegener's granulomatosis in remission. Arthritis Rheum 2007, 56:2080-2091.

8. Morgan MD, Day CJ, Piper KP, Khan N, Harper L, Moss PA, Savage CO: Patients with Wegener's granulomatosis demonstrate a relative deficiency and functional impairment of T-regulatory cells. Immunology 2010, 130:64-73.

9. Abdulahad WH, van der Geld YM, Stegeman CA, Kallenberg CG: Persistent expansion of CD4+ effector memory T cells in Wegener's granulomatosis. Kidney Int 2006, 70:938-947.

10. Abdulahad WH, Stegeman CA, Limburg PC, Kallenberg CG: Skewed distribution of Th17 lymphocytes in patients with Wegener's granulomatosis in remission. Arthritis Rheum 2008, 58:2196-2205.

11. Nogueira E, Hamour S, Sawant D, Henderson S, Mansfield N, Chavele KM, Pusey CD, Salama AD: Serum IL-17 and IL-23 levels and autoantigen- specific Th17 cells are elevated in patients with ANCA-associated vasculitis. Nephrol Dial Transplant 2010, 25:2209-2217.

12. Ettinger R, Sims GP, Robbins R, Withers D, Fischer RT, Grammer AC, Kuchen S, Lipsky PE: IL-21 and BAFF/BLyS synergize in stimulating plasma cell differentiation from a unique population of human splenic memory B cells. J Immunol 2007, 178:2872-2882.

13. Karnell $\mathrm{L}$, Ettinger R: The interplay of IL-21 and BAFF in the formation and maintenance of human B cell memory. Front Immunol 2012, 3:2.

14. Young DA, Hegen M, Ma HL, Whitters MJ, Albert LM, Lowe L, Senices M, Wu PW, Sibley B, Leathurby Y, Brown TP, Nickerson-Nutter C, Keith JC, Collins M: Blockade of the interleukin-21/interleukin-21 receptor pathway ameliorates disease in animal models of rheumatoid arthritis. Arthritis Rheum 2007, 56:1152-1163.

15. Herber D, Brown TP, Liang S, Young DA, Collins M, DunussiJoannopoulos K: IL-21 has a pathogenic role in a lupus-prone mouse model and its blockade with IL-21R.Fc reduces disease progression. J Immunol 2007, 178:3822-3830.

16. Fina D, Sarra M, Fantini MC, Rizzo A, Caruso R, Caprioli F, Stolfi C, Cardolini I, Dottori M, Boirivant M, Pallone F, Macdonald TT, Monteleone G: Regulation of gut inflammation and th17 cell response by interleukin-21. Gastroenterology 2008, 134:1038-1048.

17. Spolski R, Kashyap M, Robinson C, Yu Z, Leonard WJ: IL-21 signaling is critical for the development of type I diabetes in the NOD mouse. Proc Natl Acad Sci USA 2008, 105:14028-14033.

18. Sawalha AH, Kaufman KM, Kelly JA, Adler AJ, Aberle T, Kilpatrick J, Wakeland EK, Li QZ, Wandstrat AE, Karp DR, James JA, Merrill JT, Lipsky P, Harley JB: Genetic association of interleukin-21 polymorphisms with systemic lupus erythematosus. Ann Rheum Dis 2008, 67:458-461.

19. Festen EA, Goyette P, Scott R, Annese V, Zhernakova A, Lian J, Lefebvre C, Brant SR, Cho JH, Silverberg MS, Taylor KD, de Jong DJ, Stokkers PC, Mcgovern D, Palmieri O, Achkar JP, Xavier RJ, Daly MJ, Duerr RH, Wijmenga C, Weersma RK, Rioux JD: Genetic variants in the region harbouring IL2/IL21 associated with ulcerative colitis. Gut 2009, 58:799-804.

20. Liu Y, Helms C, Liao W, Zaba LC, Duan S, Gardner J, Wise C, Miner A, Malloy MJ, Pullinger CR, Kane JP, Saccone S, Worthington J, Bruce I, Kwok PY, Menter A, Krueger J, Barton A, Saccone NL, Bowcock AM: A genome-wide association study of psoriasis and psoriatic arthritis identifies new disease loci. PLOS Genet 2008, 4:e1000041.

21. Craft JE: Follicular helper T cells in immunity and systemic autoimmunity. Nat Rev Rheumatol 2012, 8:337-347.

22. Dolff $\mathrm{S}$, Abdulahad WH, Westra J, Doornbos-van der MB, Limburg PC, Kallenberg CG, Bijl M: Increase in IL-21 producing T-cells in patients with systemic lupus erythematosus. Arthritis Res Ther 2011, 13:R157.

23. Simpson N, Gatenby PA, Wilson A, Malik S, Fulcher DA, Tangye SG, Manku H, Vyse TJ, Roncador G, Huttley GA, Goodnow CC, Vinuesa CG, Cook MC: Expansion of circulating T cells resembling follicular helper $T$ cells is a fixed phenotype that identifies a subset of severe systemic lupus erythematosus. Arthritis Rheum 2010, 62:234-244.

24. Ma J, Zhu C, Ma B, Tian J, Baidoo SE, Mao C, Wu W, Chen J, Tong J, Yang M, Jiao Z, Xu H, Lu L, Wang S: Increased frequency of circulating follicular helper $\mathrm{T}$ cells in patients with rheumatoid arthritis. Clin Dev Immunol 2012, 2012:827480.

25. Jennette JC, Falk RJ, Andrassy K, Bacon PA, Churg J, Gross WL, Hagen EC, Hoffman GS, Hunder GG, Kallenberg CG, Mccluskey RT, Sinico RA, Rees AJ, Van Es LA, Waldherr R, Wiik A: Nomenclature of systemic vasculitides. Proposal of an international consensus conference. Arthritis Rheum 1994, 37:187-192.

26. Leavitt RY, Fauci AS, Bloch DA, Michel BA, Hunder GG, Arend WP, Calabrese LH, Fries JF, Lie JT, Lightfoot RW, Masi AT, McShane DJ, Mills JA, Stevens MB, Wallace SL, Zvaifler NJ: The American College of Rheumatology 1990 criteria for the classification of Wegener's granulomatosis. Arthritis Rheum 1990, 33:1101-1107.

27. Luqmani RA, Bacon PA, Moots RJ, Janssen BA, Pall A, Emery P, Savage C, Adu D: Birmingham Vasculitis Activity Score (BVAS) in systemic necrotizing vasculitis. QJM 1994, 87:671-678.

28. Tervaert JW, Mulder L, Stegeman C, Elema J, Huitema M, The H, Kallenberg C: Occurrence of autoantibodies to human leucocyte elastase in Wegener's granulomatosis and other inflammatory disorders. Ann Rheum Dis 1993, 52:115-120.

29. Tervaert JW, Goldschmeding R, Elema JD, van der GM, Huitema MG, van der Hem GK, The TH, von dem Borne AE, Kallenberg CG: Autoantibodies 
against myeloid lysosomal enzymes in crescentic glomerulonephritis. Kidney Int 1990, 37:799-806.

30. Savige J, Dimech W, Fritzler M, Goeken J, Hagen EC, Jennette JC, McEvoy R, Pusey C, Pollock W, Trevisin M, Wiik A, Wong R: Addendum to the International Consensus Statement on testing and reporting of antineutrophil cytoplasmic antibodies. Quality control guidelines, comments, and recommendations for testing in other autoimmune diseases. Am J Clin Pathol 2003, 120:312-318.

31. Tadema H, Abdulahad WH, Lepse N, Stegeman CA, Kallenberg CG, Heeringa P: Bacterial DNA motifs trigger ANCA production in ANCAassociated vasculitis in remission. Rheumatology (Oxford) 2011, 50:689-696.

32. Korn T, Bettelli E, Gao W, Awasthi A, Jager A, Strom TB, Oukka M, Kuchroo VK: IL-21 initiates an alternative pathway to induce proinflammatory $\mathrm{T}(\mathrm{H}) 17$ cells. Nature 2007, 448:484-487.

33. Nurieva R, Yang XO, Martinez G, Zhang Y, Panopoulos AD, Ma L, Schluns $K$, Tian Q, Watowich SS, Jetten AM, Dong C: Essential autocrine regulation by IL-21 in the generation of inflammatory T cells. Nature 2007, 448:480-483.

34. Yu D, Rao S, Tsai LM, Lee SK, He Y, Sutcliffe EL, Srivastava M, Linterman M, Zheng L, Simpson N, Ellyard Jl, Parish IA, Ma CS, Li QJ, Parish CR, Mackay CR, Vinuesa CG: The transcriptional repressor Bcl-6 directs T follicular helper cell lineage commitment. Immunity 2009, 31:457-468.

35. Nurieva Rl, Chung Y, Martinez GJ, Yang XO, Tanaka S, Matskevitch TD, Wang YH, Dong C: Bcl6 mediates the development of T follicular helper cells. Science 2009, 325:1001-1005.

36. Chung Y, Tanaka S, Chu F, Nurieva Rl, Martinez GJ, Rawal S, Wang YH, Lim H, Reynolds JM, Zhou XH, Fan HM, Liu ZM, Neelapu SS, Dong C: Follicular regulatory T cells expressing Foxp3 and Bcl-6 suppress germinal center reactions. Nat Med 2011, 17:983-988.

37. Linterman MA, Pierson W, Lee SK, Kallies A, Kawamoto S, Rayner TF, Srivastava M, Divekar DP, Beaton L, Hogan JJ, Fagarasan S, Liston A, Smith KG, Vinuesa CG: Foxp3+ follicular regulatory T cells control the germinal center response. Nat Med 2011, 17:975-982.

38. Pene J, Gauchat JF, Lecart S, Drouet E, Guglielmi P, Boulay V, Delwail A, Foster D, Lecron JC, Yssel H: Cutting edge: IL-21 is a switch factor for the production of IgG1 and lgG3 by human B cells. J Immunol 2004, 172:5154-5157.

39. Ettinger R, Sims GP, Fairhurst AM, Robbins $R$, da Silva YS, Spolski R, Leonard WJ, Lipsky PE: IL-21 induces differentiation of human naive and memory B cells into antibody-secreting plasma cells. J Immunol 2005, 175:7867-7879.

40. Kuchen S, Robbins R, Sims GP, Sheng C, Phillips TM, Lipsky PE, Ettinger R: Essential role of IL-21 in B cell activation, expansion, and plasma cell generation during CD4+ T cell-B cell collaboration. J Immunol 2007, 179:5886-5896.

41. Waite JC, Skokos D: Th17 response and inflammatory autoimmune diseases. Int J Inflam 2012, 2012:819467.

42. Hsu HC, Yang P, Wang J, Wu Q, Myers R, Chen J, Yi J, Guentert T, Tousson A, Stanus AL, Le TV, Lorenz RG, Xu H, Kolls JK, Carter RH, Chaplin DD, Williams RW, Mountz JD: Interleukin 17-producing T helper cells and interleukin 17 orchestrate autoreactive germinal center development in autoimmune BXD2 mice. Nat Immunol 2008, 9:166-175.

43. Chen Q, Yang W, Gupta S, Biswas P, Smith P, Bhagat G, Pernis AB: IRF-4binding protein inhibits interleukin-17 and interleukin-21 production by controlling the activity of IRF-4 transcription factor. Immunity 2008, 29:899-911.

44. Caruso R, Fina D, Peluso I, Stolfi C, Fantini MC, Gioia V, Caprioli F, Del Vecchio BG, Paoluzi OA, Macdonald TT, Pallone F, Monteleone G: A functional role for interleukin-21 in promoting the synthesis of the T-cell chemoattractant, MIP-3alpha, by gut epithelial cells. Gastroenterology 2007, 132:166-175

45. Liu Y, Yang B, Ma J, Wang H, Huang F, Zhang J, Chen H, Wu C: Interleukin21 induces the differentiation of human Tc22 cells via phosphorylation of signal transducers and activators of transcription. Immunology 2011, 132:540-548.

46. Ebert EC: Interleukin 21 up-regulates perforin-mediated cytotoxic activity of human intra-epithelial lymphocytes. Immunology 2009, 127:206-215

47. Liu Z, Yang L, Cui Y, Wang X, Guo C, Huang Z, Kan Q, Liu Z, Liu Y: II-21 enhances NK cell activation and cytolytic activity and induces Th17 cell differentiation in inflammatory bowel disease. Inflamm Bowel Dis 2009, 15:1133-1144.
48. Ozaki K, Spolski R, Ettinger R, Kim HP, Wang G, Qi CF, Hwu P, Shaffer DJ, Akilesh S, Roopenian DC, Morse HC, Lipsky PE, Leonard WJ: Regulation of B cell differentiation and plasma cell generation by IL-21, a novel inducer of Blimp-1 and Bcl-6. J Immunol 2004, 173:5361-5371.

49. Linterman MA, Beaton L, Yu D, Ramiscal RR, Srivastava M, Hogan JJ, Verma NK, Smyth MJ, Rigby RJ, Vinuesa CG: IL-21 acts directly on B cells to regulate $\mathrm{BCl}-6$ expression and germinal center responses. J Exp Med 2010, 207:353-363.

50. Slot MC, Tervaert JW, Boomsma MM, Stegeman CA: Positive classic antineutrophil cytoplasmic antibody (C-ANCA) titer at switch to azathioprine therapy associated with relapse in proteinase 3-related vasculitis. Arthritis Rheum 2004, 51:269-273.

51. Pierrot-Deseilligny DC, Pouchot J, Pagnoux C, Coste J, Guillevin L: Predictors at diagnosis of a first Wegener's granulomatosis relapse after obtaining complete remission. Rheumatology (Oxford) 2010, 49:2181-2190.

52. Abdulahad WH, Kallenberg CG, Limburg PC, Stegeman CA: Urinary CD4+ effector memory $T$ cells reflect renal disease activity in antineutrophil cytoplasmic antibody-associated vasculitis. Arthritis Rheum 2009, 60:2830-2838.

doi:10.1186/ar4247

Cite this article as: Abdulahad et al:: Increased frequency of circulating IL-21 producing Th-cells in patients with granulomatosis with polyangiitis (GPA). Arthritis Research \& Therapy 2013 15:R70.

\section{Submit your next manuscript to BioMed Central and take full advantage of:}

- Convenient online submission

- Thorough peer review

- No space constraints or color figure charges

- Immediate publication on acceptance

- Inclusion in PubMed, CAS, Scopus and Google Scholar

- Research which is freely available for redistribution

Submit your manuscript at www.biomedcentral.com/submit
C Biomed Central 